\title{
Platycoside O, a New Triterpenoid Saponin from the Roots of Platycodon grandiflorum
}

\author{
Wen-Wei Fu ${ }^{1,2,3,4, *}$, Jin-Nan Fu ${ }^{5}$, Wen-Meng Zhang ${ }^{6}$, Li-Xin Sun ${ }^{6}$, Yue-Hu Pei ${ }^{6}$ and \\ Ping Liu ${ }^{3.4} *$
}

1 Institute of Liver Diseases, Shanghai Shuguang Hospital, Shanghai 201203, China

2 Shanghai Clinical Key Laboratory of Traditional Chinese Medicine, Shanghai Shuguang Hospital, Shanghai 201203, China

3 Key Laboratory of Liver and Kidney Diseases, Shanghai University of Traditional Chinese Medicine, Shanghai 201203, China

4 E-Institute of Traditional Chinese Medicine Internal Medicine in Shanghai University, Shanghai University of Traditional Chinese Medicine, Shanghai 201203, China

5 Institute of Microbiology, Jiangxi Academy of Sciences, Nanchang 330029, China

6 School of Pharmacy, Shenyang Pharmaceutical University, Shenyang 110016, China

* Authors to whom correspondence should be addressed; E-Mails: fuwenwei@yahoo.com (W.-W.F.); liuliver@vip.sina.com (P.L.); Tel.: +86-21-20256531; Fax: +86-21-20256521.

Received: 25 March 2011; in revised form: 13 May 2011 / Accepted: 18 May 2011 /

Published: 26 May 2011

Abstract: A new unusual minor triterpenoid saponin, platycoside $\mathrm{O}$ (1), was isolated from the $75 \%$ EtOH extract obtained from the roots of Platycodon grandiflorum, together with four known saponins: platycoside M-3 (2), platycoside J (3), platycoside F (4) and platycoside B (5). The structure of 1 was determined as 3-O- $\beta$-D-glucopyranosyl- $(1 \rightarrow 6)-\beta$ D-glucopyranosyl-2 $\beta, 3 \beta, 16 \alpha, 23$-tetrahydroxyolean-12-en-24-methoxyl, 24-oxo-28-oic acid 28 -O- $\beta$-D-xylopyranosyl-( $1 \rightarrow 4)-\alpha$-L-rhamnopyranosyl- $(1 \rightarrow 2)-\alpha$-L-arabinopyranoside $\quad$ on the basis of spectral analysis and chemical evidence.

Keywords: platycoside O; Platycodon grandiflorum; triterpenoid saponin 


\section{Introduction}

Platycodon grandiflorum (Campanulaceae) is a species of perennial flowering plant of the family Campanulaceae and the only member of the genus Platycodon. In traditional Oriental medicine, its root (Radix Platycodi) has been extensively used since ancient times as a traditional drug to treat coughs, colds, upper respiratory tract infections, sore throats, tonsillitis, and chest congestion [1]. In the northeastern of China and Korea, the root is also a popular ingredient in salads and traditional cuisine. Chemical investigation of $\mathrm{P}$. radix revealed that triterpenoid saponins were the main chemical components [1], which exhibit a variety of pharmacological activities, such as anti-inflammatory [2,3], protective effects on the hepatotoxicity induced by chemicals [4,5], anti-antioxidant [6], anti-cancer [7,8] and adjuvant against hepatitis $B$ antigen $[9,10]$. Till date, more than 40 triterpenoid saponins have been isolated from the roots of the plant [1,11-21].

In our previous papers, we reported the isolation and structural elucidation of eleven new triterpenoid saponins, including several unusual A-ring lactone triterpenoid saponins, from the roots of $P$. grandiflorum A. DC [13-16]. Further investigation on the polar fractions of P. grandiflorum led to the isolation from the $\mathrm{EtOH}$ extract obtained from the roots of a new unusual minor triterpenoid saponin based on the sapogenin platycogenic acid A, named platycoside O, together with four known compounds. To the best of our knowledge, the triterpenoid saponins based on the sapogenin platycogenic acid A had been isolated only in the plant and reported in a few publications $[19,22]$.

\section{Results and Discussion}

The $75 \% \mathrm{EtOH}$ extract from the roots of Platycodon grandiflorum were partitioned with aqueous EtOAc. The aqueous layer was separated by a macroreticular resin column to give the $60 \% \mathrm{EtOH}$ eluates that upon drying afforded the total saponins. The total saponins were chromatographed on silica gel, a reverse-phase column, and finally on HPLC to afford the compound $\mathbf{1}$ and four known compounds (Figure 1).

Figure 1. Compounds 1-5 from Platycodon grandiflorum.

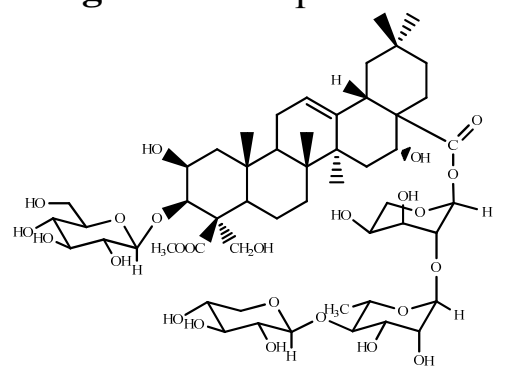

Platycoside O (1)

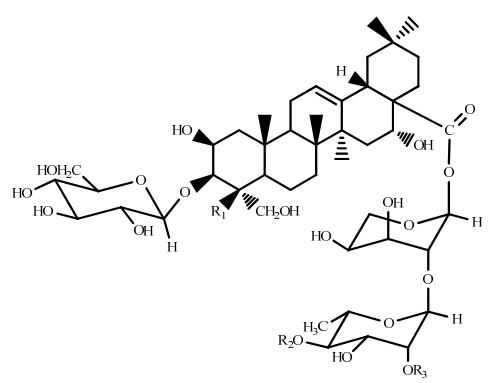

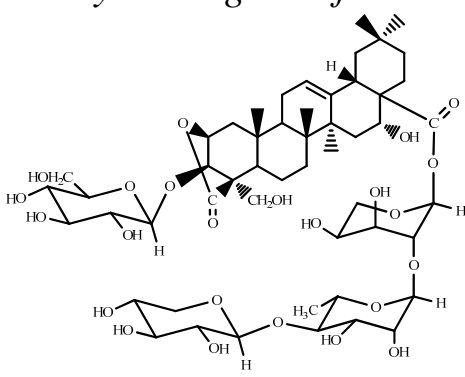

Platycoside M-3 (2)

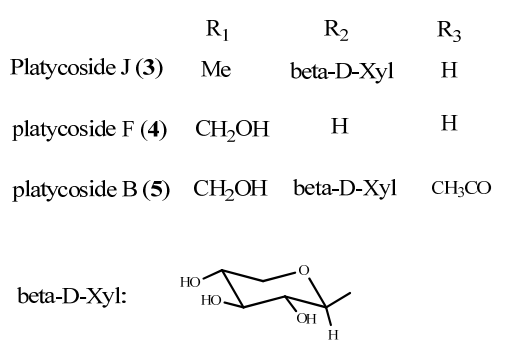


Platycoside O (1) was a white amorphous powder, and its molecular formula was assigned to be $\mathrm{C}_{53} \mathrm{H}_{84} \mathrm{O}_{25}$ based on the high-resolution (HR)-FAB-MS spectrum. The spectral features and physicochemical properties revealed 1 to be a triterpenoid saponin. The IR spectrum exhibited absorptions at $3,421 \mathrm{~cm}^{-1}(\mathrm{OH}), 1,738 \mathrm{~cm}^{-1}$ (ester carbonyl), 1,633 $\mathrm{cm}^{-1}$ (trisubstituted double bond), and $1,384 \mathrm{~cm}^{-1}$ (gem-dimethyl). Five tertiary methyl groups $(\delta 0.99,1.14 \times 2,1.33,1.55,1.76)$ and one olefinic proton ( $\delta 5.63$, br s) were observed in the ${ }^{1} \mathrm{H}-\mathrm{NMR}$ spectrum. The ${ }^{13} \mathrm{C}-\mathrm{NMR}$ spectrum showed five $\mathrm{sp}^{3}$ carbons at $\delta 17.6,17.8,24.8,27.2$, and 33.3, two $\mathrm{sp}^{2}$ olefinic carbons at $\delta 123.1$ and 144.4 , four oxygenated methylene and methine carbons at $\delta 63.7,70.2,74.0$, and 85.1 (Table 1), two carbonyl carbons at $\delta 170.5$, and 175.9. The information on the ${ }^{1} \mathrm{H}-\mathrm{NMR}$ spectrum coupled with the

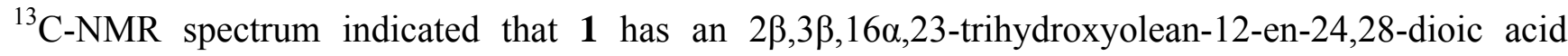
skeleton [22]. The HMBC spectrum showed that correlation between $\mathrm{H}\left(\delta_{\mathrm{H}} 3.69\right)$ of a methoxy group $\left(\delta_{\mathrm{H}} 3.69, \delta_{\mathrm{C}} 52.1\right)$ and the carbon $\left(\delta_{\mathrm{C}} 170.5\right)$ at the C-24 carboxy group. A $2 \mathrm{D}$ NMR experiments such as COSY, DEPT, HMQC and HMBC and by the comparison with the data in the literature revealed that the aglycon was $2 \beta, 3 \beta, 16 \alpha, 23$-trihydroxyolean-12-en-24-methoxyl, 24-oxo-28-oic acid (24-methyl platycogenic acid A).

The chemical shifts of C-3 $(\delta$ 85.1) and C-28 $(\delta$ 175.9) revealed that 1 was a bisdesmosidic glycoside. The ${ }^{1} \mathrm{H}$ - and ${ }^{13} \mathrm{C}-\mathrm{NMR}$ spectra of 1 exhibited four sugar anomeric protons at $\delta 5.18(\mathrm{~d}$, $J=8.0 \mathrm{~Hz}), 5.27(\mathrm{~d}, J=8.0 \mathrm{~Hz}), 5.78(\mathrm{br} \mathrm{s})$, and $6.47(\mathrm{~d}, J=2.5 \mathrm{~Hz})$ and carbons at $\delta$ 93.6, 101.2, 106.4, and 106.8 (Table 1). In the ${ }^{1} \mathrm{H}-\mathrm{NMR}$ spectrum, one doublet methyl signal at $\delta 1.74(\mathrm{~J}=5.5 \mathrm{~Hz})$ belonging to rhamnose was observed. Acid hydrolysis of 1 gave a 1:1:1:1 ratio of arabinose, rhamnose, xylose, and glucose, which were analyzed by gas chromatography as their alditol acetates. The absolute configurations of sugars were shown to be L-arabinose, L-rhamnose, D-xylose, and D-glucose according to the method reported by Hara and coworkers $[14,15]$.

All the monosaccharides of 1 were in pyranose forms, as determined by their ${ }^{1} \mathrm{H}-$ and ${ }^{13} \mathrm{C}-\mathrm{NMR}$ spectral data as well as $2 \mathrm{D}$ NMR experiments. The $\beta$-anomeric configurations of the D-glucose and D-xylose units were determined by their ${ }^{3} J_{H 1, H 2}$ coupling constants $(7.0-8.0 \mathrm{~Hz})$. The $\alpha$-anomeric configuration of the L-arabinose was determined by its ${ }^{3} J_{\mathrm{H} 1, \mathrm{H} 2}$ coupling constants $(2.5 \mathrm{~Hz})$ and $J_{\mathrm{C} 1, \mathrm{H} 1}$ coupling constant $(170 \mathrm{~Hz})[14,15]$. The L-rhamnose was determined to have the $\alpha$-configuration based on the broad singlet of its anomeric proton $[14,15]$. The sugar linkage at C-3 were determined on the basis of the HMBC spectrum which showed correlation between a proton signal at $\delta 5.27$ (glc-H-1) and a carbon signal at $\delta 85.1$ due to C-3 of the aglycone moiety (see Figure 2). The sequence of the sugar chain at C-28 was established from the following HMBC correlations between H-1 $(\delta 5.18)$ of terminal xylose and C-4 $(\delta$ 83.6) of rhamnose, H-1 $(\delta 5.78)$ of rhamnose and C-2 $(\delta 75.2)$ of arabinose, $\mathrm{H}-1$ ( $\delta$ 6.47) of arabinose and C-28 ( $\delta$ 175.9) (Figure 2$)$. On the basis of the above evidence, platycoside $\mathrm{O}(1)$ was identified to be 3-O- $\beta$-D-glucopyranosyl-2 $\beta, 3 \beta, 16 \alpha, 23$-tetrahydroxyolean-12-en24-methoxyl, 24-oxo-28-oic acid 28-O- $\beta$-D-xylopyranosyl- $(1 \rightarrow 4)-\alpha$-L-rhamnopyranosyl- $(1 \rightarrow 2)-\alpha$-Larabinopyranoside.

The four known saponins were identified as platycoside M-3 (2), platycoside J (3), platycoside F (4), and platycoside B (5) through comparison of their UV, IR, NMR and MS data with literature values $[14,15]$. 
Table 1. ${ }^{13} \mathrm{C}$ and ${ }^{1} \mathrm{H}-\mathrm{NMR}$ data of $\mathbf{1}$ in pyridine- $d_{5}(500 \mathrm{MHz}$ for $\mathrm{H}, 150 \mathrm{MHz}$ for $\mathrm{C}$ ).

\begin{tabular}{|c|c|c|c|c|c|}
\hline No & $\mathrm{C}$ & $\mathbf{H}$ & No & $\mathrm{C}$ & $\mathbf{H}$ \\
\hline \multirow[t]{2}{*}{1} & 45.1 & $1.45(1 \mathrm{H}, \mathrm{o})$ & \multicolumn{3}{|c|}{ 3-O-Glu } \\
\hline & & $2.03-2.12(1 \mathrm{H}, \mathrm{m})$ & 1 & 106.4 & $5.27(1 \mathrm{H}, \mathrm{d}, J=8.0 \mathrm{~Hz})$ \\
\hline 2 & 70.2 & $4.77(1 \mathrm{H}$, br s $)$ & 2 & 74.9 & $3.99(1 \mathrm{H}, \mathrm{t}, J=9.0 \mathrm{~Hz})$ \\
\hline 3 & 85.1 & $4.58(1 \mathrm{H}$, br s $)$ & 3 & 78.6 & $4.05(1 \mathrm{H}, \mathrm{t}, J=7.5,9.0 \mathrm{~Hz})$ \\
\hline 4 & 48.2 & & 4 & 73.0 & $4.37-4.42(1 \mathrm{H}, \mathrm{m})$ \\
\hline 5 & 47.8 & $1.90-1.94(1 \mathrm{H}, \mathrm{m})$ & 5 & 77.0 & $4.46-4.49(1 \mathrm{H}, \mathrm{m})$ \\
\hline \multirow[t]{2}{*}{6} & 19.1 & $1.92-1.94(1 \mathrm{H}, \mathrm{m})$ & 6 & 63.2 & $4.83(1 \mathrm{H}, \mathrm{br} \mathrm{d}, J=11.0 \mathrm{~Hz})$ \\
\hline & & $1.30-1.35(1 \mathrm{H}, \mathrm{m})$ & & & $3.95(1 \mathrm{H}, \mathrm{dd}, J=4.5,11.0 \mathrm{~Hz})$ \\
\hline \multirow[t]{2}{*}{7} & 33.7 & $1.65-1.76(1 \mathrm{H}, \mathrm{m})$ & & & \\
\hline & & $1.48(1 \mathrm{H}, \mathrm{d}-\mathrm{like}, J=11.5 \mathrm{~Hz})$ & \multicolumn{2}{|c|}{ C-28-Ara } & \\
\hline 8 & 40.3 & & 1 & 93.6 & $6.47(1 \mathrm{H}, \mathrm{d}, J=2.5 \mathrm{~Hz})$ \\
\hline 9 & 47.8 & $1.90-1.94(1 \mathrm{H}, \mathrm{m})$ & 2 & 75.2 & $4.53-4.58(1 \mathrm{H}, \mathrm{m})$ \\
\hline 10 & 37.2 & & 3 & 70.1 & $4.50-4.54(1 \mathrm{H}, \mathrm{m})$ \\
\hline \multirow[t]{2}{*}{11} & 24.2 & $2.08(1 \mathrm{H}, \mathrm{d}-$ like, $J=17.0 \mathrm{~Hz})$ & 4 & 66.2 & $4.37-4.45(1 \mathrm{H}, \mathrm{m})$ \\
\hline & & $2.14(1 \mathrm{H}, \mathrm{d}-$ like, $J=17.5 \mathrm{~Hz})$ & 5 & 63.2 & $4.53-4.56(1 \mathrm{H}, \mathrm{m})$ \\
\hline 12 & 123.1 & $5.63(1 \mathrm{H}, \mathrm{t}-\mathrm{like})$ & & & $4.26(1 \mathrm{H}, \mathrm{brd}, J=13.5 \mathrm{~Hz})$ \\
\hline 13 & 144.4 & & & & \\
\hline 14 & 42.3 & & Rha & & \\
\hline \multirow[t]{2}{*}{15} & 36.1 & $2.31(1 \mathrm{H}, \mathrm{d}-$ like, $J=12.0 \mathrm{~Hz})$ & 1 & 101.2 & $5.78(1 \mathrm{H}$, br s $)$ \\
\hline & & $1.81(1 \mathrm{H}, \mathrm{dd}, J=3.0,15.0 \mathrm{~Hz})$ & 2 & 72.0 & $4.57(1 \mathrm{H}$, br d, $J=3.0 \mathrm{~Hz})$ \\
\hline 16 & 74 & $5.25(1 \mathrm{H}, \mathrm{d}-$ like, $J=3.6 \mathrm{~Hz})$ & 3 & 72.7 & $4.61(1 \mathrm{H}, \mathrm{dd}, J=3.0,8.5 \mathrm{~Hz})$ \\
\hline 17 & 49.6 & & 4 & 83.6 & $4.39(1 \mathrm{H}, \mathrm{t}, J=9.5 \mathrm{~Hz})$ \\
\hline 18 & 41.4 & $3.57(1 \mathrm{H}, \mathrm{dd}, J=4.0,14.0 \mathrm{~Hz})$ & 5 & 68.6 & $4.42(1 \mathrm{H}, \mathrm{dq}, J=5.5,9.5 \mathrm{~Hz})$ \\
\hline \multirow[t]{2}{*}{19} & 47.1 & $2.75(1 \mathrm{H}, \mathrm{t}-$ like, $J=13.0,14.0 \mathrm{~Hz})$ & 6 & 18.4 & $1.74(3 \mathrm{H}, \mathrm{d}, J=5.5 \mathrm{~Hz})$ \\
\hline & & $1.35(1 \mathrm{H}, \mathrm{dd}, J=4.0,13.0 \mathrm{~Hz})$ & & & \\
\hline 20 & 30.9 & & Xyl & & \\
\hline \multirow[t]{2}{*}{21} & 36 & $2.40(1 \mathrm{H}, \mathrm{dt}, J=5.0,12.0 \mathrm{~Hz})$ & 1 & 106.8 & $5.18(1 \mathrm{H}, \mathrm{d}, J=8.0 \mathrm{~Hz})$ \\
\hline & & $1.29(1 \mathrm{H}, \mathrm{d}-$ like, $J=11.5 \mathrm{~Hz})$ & 2 & 76.0 & $4.03-4.08(1 \mathrm{H}, \mathrm{m})$ \\
\hline \multirow[t]{2}{*}{22} & 32.1 & $2.25-2.35(1 \mathrm{H}, \mathrm{m})$ & 3 & 77.8 & $4.18(1 \mathrm{H}, \mathrm{t}, J=8.5 \mathrm{~Hz})$ \\
\hline & & $2.20(1 \mathrm{H}, \mathrm{dd}, J=5.5,12.5 \mathrm{~Hz})$ & 4 & 71.0 & $4.07-4.24(1 \mathrm{H}, \mathrm{m})$ \\
\hline \multirow[t]{2}{*}{23} & 63.7 & $5.02(1 \mathrm{H}, \mathrm{o})$ & 5 & 67.4 & $4.15-4.25(1 \mathrm{H}, \mathrm{m})$ \\
\hline & & $4.09(1 \mathrm{H}, \mathrm{m})$ & & & $3.50(1 \mathrm{H}, \mathrm{t}-$ like, $J=11.0 \mathrm{~Hz})$ \\
\hline 24 & 170.5 & & & & \\
\hline 25 & 17.8 & $1.55(3 \mathrm{H}, \mathrm{s})$ & & & \\
\hline 26 & 17.6 & $1.14(3 \mathrm{H}, \mathrm{s})$ & & & \\
\hline 27 & 27.2 & $1.76(3 \mathrm{H}, \mathrm{s})$ & & & \\
\hline 28 & 175.9 & & & & \\
\hline 29 & 33.3 & $0.99(3 \mathrm{H}, \mathrm{s})$ & & & \\
\hline 30 & 24.8 & $1.14(3 \mathrm{H}, \mathrm{s})$ & & & \\
\hline- & 52.1 & $3.69(3 \mathrm{H}, \mathrm{s})$ & & & \\
\hline $\mathrm{OCH}_{3}$ & & & & & \\
\hline
\end{tabular}


Figure 2. The structure and selected HMBC correlations of $\mathbf{1 .}$

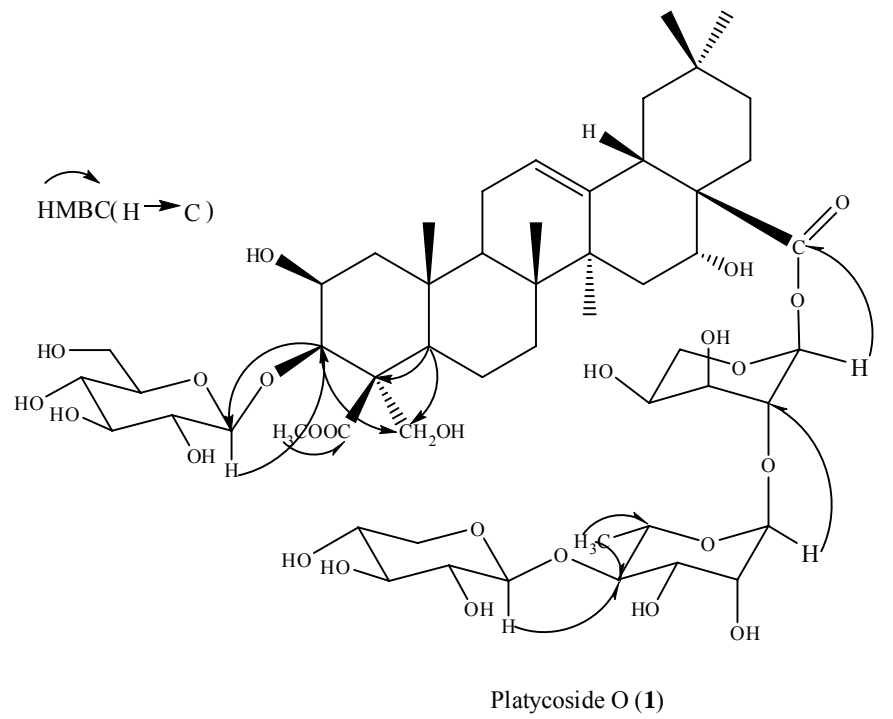

\section{Experimental}

\subsection{General}

FAB-MS and HR-FAB-MS spectral were recorded on a JEOL JMS-SX 102A mass spectrometer. IR spectra were measured with a Bruker IFS-55 infrared spectrometer. ${ }^{1} \mathrm{H}$ - and ${ }^{13} \mathrm{C}-\mathrm{NMR}$ spectra were recorded with a JEOL a 500/600 FT NMR spectrometer. Chemical shifts were reported in parts per million on the $d$ scale with TMS as an internal standard. Silica gel (Qingdao Haiyang Chemical Co., Ltd. 200-300 mesh) and Lichroprep RP-18 (Merck) were used for silica gel column chromatography and MPLC. Preparative HPLC was performed using an octadecyl silica (ODS) column (Pegasil ODS, Senshu Pak, $250 \mathrm{~mm} \times 10 \mathrm{~mm}$ i.d.) on a Hitachi liquid chromatography system with an RI detector. Gas liquid chromatography was carried out on a Shimadzu GC-7A under the following conditions: column, $3 \%$ ECNSS-M $(2 \mathrm{~m} \times 0.3 \mathrm{~mm})$; column temperature, $190{ }^{\circ} \mathrm{C}$; injection temperature, $210{ }^{\circ} \mathrm{C}$; carrier gas, $\mathrm{N}_{2}$; and flow rate, $25 \mathrm{~mL} / \mathrm{min}$. Spots were visualized by spraying with ethanol- $10 \% \mathrm{H}_{2} \mathrm{SO}_{4}$ and heating $\left(110^{\circ} \mathrm{C}, 5 \mathrm{~min}\right)$.

\subsection{Plant Material}

The roots of $P$. grandiflorum were collected from Shenyang, Liaoning Province, China, in 2003 and were taxonomically identified by Professor Sun Qi-Shi of Shenyang Pharmaceutical University. A voucher specimen (No. 20030321) is deposited at the Herbarium of Shenyang Pharmaceutical University.

\subsection{Extraction and Isolation}

The air-dried roots of $P$. grandiflorum $(10 \mathrm{~kg})$ were pulverized and extracted with $75 \% \mathrm{EtOH}$ (ethanol:water $=3: 1, \mathrm{v} / \mathrm{v}$ ) three times under reflux. The combined extract was evaporated in vacuo, suspended in water, and then partitioned with EtOAc. The aqueous layer was chromatographed over a macroporous resin D101 column and eluted with $\mathrm{H}_{2} \mathrm{O}, 60 \% \mathrm{EtOH}$, and 95\% EtOH. The 60\% EtOH elution was evaporated under a vacuum to obtain a residue $(180 \mathrm{~g})$. The residue $(80 \mathrm{~g})$ was fractioned 
on silica gel (solvent, $\mathrm{CHCl}_{3}-\mathrm{MeOH}=50: 1-1: 1$, v/v) to give four fractions (Fr.I-IV). Fraction III $\left(27.0 \mathrm{~g}\right.$ ) was applied onto a silica gel column (solvent, $\mathrm{CHCl}_{3}-\mathrm{MeOH}-\mathrm{H}_{2} \mathrm{O}=30: 10: 1 \rightarrow 6: 4: 1$, v/v/v) to give a crude saponin sub-fractions (Fr A-C). Fraction $\mathrm{C}(18.0 \mathrm{~g})$ was chromatographed on a silica gel column (solvent, EtOAc- EtOH- $\mathrm{H}_{2} \mathrm{O}=9: 1: 0.5 \rightarrow$ 85:15:7.5, v/v/v), followed by MPLC [Lichroprep RP-18 (Merck), solvent, $\left.\mathrm{MeOH}-\mathrm{H}_{2} \mathrm{O}(2: 3 \rightarrow 7: 3, \mathrm{v} / \mathrm{v})\right]$ and finally by semi-preparative HPLC $\left(\mathrm{MeOH}-\mathrm{H}_{2} \mathrm{O}=52: 48\right)$ to give three new compounds $1(7.6 \mathrm{mg}), 2(8.1 \mathrm{mg})$ and $3(8.2 \mathrm{mg})$. Further purification of Fraction B $(5.0 \mathrm{~g})$ by MPLC [Lichroprep RP-18 (Merck), solvent, $\mathrm{MeOH}-\mathrm{H}_{2} \mathrm{O}$ $(2: 3 \rightarrow 7: 3, \mathrm{v} / \mathrm{v})]$ and finally by semi-preparative $\mathrm{HPLC}\left(\mathrm{MeOH}-\mathrm{H}_{2} \mathrm{O}=45: 55, \mathrm{v} / \mathrm{v}\right)$ to give three compounds 4 (15 mg) and 5 (6.2 $\mathrm{mg})$.

\subsection{Characterization of Platycoside O (1)}

Obtained as a white amorphous powder; IR $v_{\max }$ : 3421, 2926, 1738, 1633, 1384, 1226 and $1042 \mathrm{~cm}^{-1}$; HR-FAB-MS m/z: $1143.5130[\mathrm{M}+\mathrm{Na}]^{+}$(Calcd. for $\left.\mathrm{C}_{53} \mathrm{H}_{84} \mathrm{O}_{25} \mathrm{Na}, 1143.5200\right)$; ${ }^{1} \mathrm{H}-\mathrm{NMR}$ (pyridine- $d_{5}, 500 \mathrm{MHz}$ ) and ${ }^{13} \mathrm{C}-\mathrm{NMR}$ (pyridine- $d_{5}, 150 \mathrm{MHz}$ ): see Table 1.

\subsection{Acid Hydrolysis of 1}

Compound $1\left(2.0 \mathrm{mg}\right.$ ) were heated $1 \mathrm{M} \mathrm{HCl}$ (dioxane- $\mathrm{H}_{2} \mathrm{O}, 1: 1,1 \mathrm{~mL}$ ) at $90{ }^{\circ} \mathrm{C}$ for $3 \mathrm{~h}$ in a water bath. Dioxane was removed, the solution was extracted with EtOAc $(1 \mathrm{~mL} \times 3)$, and the EtOAc was removed. The monosaccharide portions were analyzed by gas chromatography after conversion of the hydrolysates into corresponding alditol acetates. The arabinitol, glucitol, rhamnitol and xylitol acetates from compound 1 were detected in a ratio of 1:1:1:1 respectively using gas chromatography analysis. The absolute configurations of the sugars were determined according to the method reported by Hara and coworkers $[14,15]$ using gas chromatography with the following conditions: column: $3 \%$ ECNSS-M $\left(2 \mathrm{~m} \times 0.3 \mathrm{~mm}\right.$ ); column temperature: $190{ }^{\circ} \mathrm{C}$; injection temperature: $210^{\circ} \mathrm{C}$. The absolute configurations of the sugars were determined as D-xylose, L-arabinose, L-rhamnose and D-glucose by comparison of its retention times with those of authentic sample [14,15].

\section{Conclusions}

During the phytochemical survey of the roots extract of Platycodon grandiflorum, a new unusual minor triterpenoid saponin $\mathbf{1}$ was isolated and identified as platycoside $\mathrm{O}$ on the basis of spectral analysis and chemical evidence.

\section{Acknowledgments}

The authors expressed their gratitude to Tadahiro Takeda (Kyoritsu University of Pharmacy, Japan) for providing the 500 or $600 \mathrm{MHz}$ NMR and HR-FAB-MS data. This work was partly supported by National S\&T major special project for new innovative drug (2009ZX09311-003) and China Postdoctoral Science Foundation (20090460644). 


\section{References}

1. World Health Organization. Radix Platycodi. In WHO Monographs on Selected Medicinal Plants; World Health Organization: Geneva, Switzerland, 1999; Volume 1, pp. 213-220.

2. Ahn, K.S.; Noh, E.J.; Zhao, H.L.; Jung, S.H.; Kang, S.S.; Kim, Y.S. Inhibition of inducible nitric oxide synthase and cyclooxygenase II by Platycodon grandiflorum saponins via suppression of nuclear factor-kappaB activation in RAW 264.7 cells. Life Sci. 2005, 76, 2315-2328.

3. Hong, S.; Yong, Y.; Kang, K.; Shin, S.Y.; Lee, Y.H.; Lim, Y. NF-kappa B Activation by compounds found in Platycodon grandiflorum extract. J. Microbiol. Biotechnol. 2009, 19, 556-559.

4. Lee, K.J.; Choi, J.H.; Kim, H.G.; Han, E.H.; Hwang, Y.P.; Lee, Y.C.; Chung, Y.C.; Jeong, H.G. Protective effect of saponins derived from the roots of Platycodon grandiflorum against carbon tetrachloride induced hepatotoxicity in mice. Food Chem. Toxicol. 2008, 46, 1778-1785.

5. Khanal, T.; Choi, J.H.; Hwang, Y.P.; Chung, Y.C.; Jeong, H.G. Saponins isolated from the root of Platycodon grandiflorum protect against acute ethanol-induced hepatotoxicity in mice. Food Chem. Toxicol. 2009, 47, 530-535.

6. Fu, X.J.; Liu, H.B.; Wang, P.; Guan, H.S. A study on the antioxidant activity and tissues selective inhibition of lipid peroxidation by saponins from the roots of Platycodon grandiflorum. Am. J. Chin. Med. 2009, 37, 967-975.

7. Kim, M.O.; Moon, D.O.; Choi, Y.H.; Shin, D.Y.; Kang, H.S.; Choi, B.T.; Lee, J.D.; Li, W.; Kim, G.Y. Platycodin D induces apoptosis and decreases telomerase activity in human leukemia cells. Cancer Lett. 2008, 261, 98-107.

8. Lee, K.J.; Hwang, S.J.; Choi, J.H.; Jeong, H.G. Saponins derived from the roots of Platycodon grandiflorum inhibit HT-1080 cell invasion and MMPs activities: Regulation of NF-kappaB activation via ROS signal pathway. Cancer Lett. 2008, 268, 233-243.

9. Xie, Y.; Sun, H.X.; Li, D. Platycodin D is a potent adjuvant of specific cellular and humoral immune responses against recombinant hepatitis B antigen. Vaccine 2009, 27, 757-764.

10. Xie, Y.; He, S.W.; Sun, H.X.; Li, D. Platycodin D2 improves specific cellular and humoral responses to hepatitis B surface antigen in mice. Chem. Biodivers. 2010, 7, 178-185.

11. Kim, Y.S.; Kim, J.S.; Choi, S.U.; Kim, J.S.; Lee, H.S.; Roh, S.H.; Jeong, Y.C.; Kim, Y.K.; Ryu, S.Y. Isolation of a new saponin and cytotoxic effect of saponins from the root of Platycodon grandiflorum on human tumor cell lines. Planta Med. 2005, 71, 566-568.

12. He, Z.; Qiao, C.; Han, Q.; Wang, Y.; Ye, W.; Xu, H. New triterpenoid saponins from the roots of Platycodon grandiflorum. Tetrahedron 2005, 61, 2211-2215.

13. Fu, W.W.; Dou, D.Q.; Shimizu, N.; Takeda, T.; Pei, Y.H.; Chen, Y.J. Studies on the chemical constituents from the roots of Platycodon grandiflorum. J. Nat. Med. 2006, 60, 68-72.

14. Fu, W.W.; Shimizu, N.; Dou, D.Q.; Takeda, T.; Fu, R.; Pei, Y.H.; Chen, Y.J. Five new triterpenoid saponins from the roots of Platycodon grandiflorum. Chem. Pharm. Bull. 2006, 54, 557-560.

15. Fu, W.W.; Shimizu, N.; Takeda, T.; Dou, D.Q.; Chen, B.H.; Pei, Y.H.; Chen, Y.J. New A-ring lactone triterpenoid saponins from the roots of Platycodon grandiflorum. Chem. Pharm. Bull. 2006, 54, 1285-1287. 
16. Fu, W.W.; Dou, D.Q.; Zhao, C.J.; Shimizu, N.; Pei, Y.P.; Pei, Y.H.; Chen, Y.J.; Takeda, T. Triterpenoid saponins from Platycodon grandiflorum. J. Asian Nat. Prod. Res. 2007, 9, 35-40.

17. Zhang, L.; Liu, Z.H.; Tian, J.K. Cytotoxic triterpenoid saponins from the roots of Platycodon grandiflorum. Molecules 2007, 12, 832-841.

18. Li, W.; Xiang, L.; Zhang, J.; Zheng, Y.N.; Han, L.K.; Saoto, M. A new triterpenoid saponin from the roots of Platycodon grandiflorum. Chin.Chem. Lett. 2007, 18, 306-308.

19. Choi, Y.H.; Yoo, D.S.; Choi, C.W.; Cha, M.R.; Kim, Y.S.; Lee, H.S.; Lee, K.R.; Ryu, S.Y. Platyconic acid A, a genuine triterpenoid saponin from the roots of Platycodon grandiflorum. Molecules 2008, 13, 2871-2879.

20. Li, W.; Zhang, W.; Xiang, L.; Wang, Z.; Zheng, Y.N.; Wang, Y.P.; Zhang, J.; Chen. L. Platycoside N: A new oleanane-type triterpenoid saponin from the roots of Platycodon grandiflorum. Molecules 2010, 15, 8702-8708.

21. Choi, Y.H.; Yoo, D.S.; Cha, M.R.; Choi, C.W.; Kim, Y.S.; Choi, S.U.; Lee, K.R.; Ryu, S.Y. Antiproliferative effects of saponins from the roots of Platycodon grandiflorum on cultured human tumor cells. J. Nat. Prod. 2010, 73, 1863-1867.

22. Ishii, H.; Tori, K.; Tozyo, T.; Yoshimura, Y. Saponins from Roots of Platycodon grandiflorurn. Part 2. Isolation and Structure of New Triterpene Glycosides. J. Chem. Soc. Perkin Trans. 1 1984, 661-668.

Sample Availability: Samples of the compounds 1-5 are available from the authors.

(C) 2011 by the authors; licensee MDPI, Basel, Switzerland. This article is an open access article distributed under the terms and conditions of the Creative Commons Attribution license (http://creativecommons.org/licenses/by/3.0/). 